\title{
Delimiting working time from rest time in the case of workers residing at the workplace
}

PhD. student Răzvan ANGHEL ${ }^{1}$

\begin{abstract}
The article presents the particular problems encountered in the process of delimiting working time from rest time in the case of workers who, due to the specific nature of their work and its organization, imposed by the employer, reside at the workplace, in which casethe question arises whether and under what conditions, the inactive periods spent by workers in their own residence may be included in working time. In order to identify these issues and possible solutions, the jurisprudence of the Court of Justice of the European Union is analyzed in order to establish principles applicable in this situation, as well as the national jurisprudence of Romania and that of other EU Member States, which is relevant in view of the common regulation of working time for all those States by Directive 2003/88. The practical implications of these issues are important from the perspective of the employer's obligation to respect the maximum weekly working time. In the presented conclusions, some criteria for the delimitation of working time from the rest time in this case are proposed, namely certain conditions, the fulfillment of which must be checked on a case-by-case basis.
\end{abstract}

Keywords: working time, rest time, workplace, residence

\section{JEL Classification: $\mathrm{K} 31$}

\section{Introduction}

In the case-law of the Court of Justice of the European Union (CJEU), the concept of working time defined by Directive 2003/88 has been developed to include periods of time in which the employees are at work place without actually performing the work ${ }^{2}$ or they are in their own residence, notworking, remaining at

\footnotetext{
${ }^{1}$ Răzvan Anghel - Faculty of Law, University of Bucharest; Judge, Constanta Court of Appeal, President Civil Division I, Romania, anghel.razvan@drept.unibuc.ro.

${ }^{2}$ CJEU judgement of 03.10.2000, in case C-303/98, regarding Sindicato de Médicos de Asistencia Pública (Simap) v. Conselleria de Sanidad y Consumo de la Generalidad Valenciana; see Răzvan Anghel, Timpul de lucru și timpul de odihnă - Jurisprudenţa Curții de Justiție a Uniunii Europene, Ed. Universul Juridic, Bucharest, 2017, p. 75; CJEU, judgement of 9.09.2003, in case C-151/02, regarding Landeshauptstadt Kiel v. Norbert Jaeger, ECLI:EU:C:2003:437, par. 44-71 of the reasoning and the operative part; judgement of 01.12.2005, in case C-14/04, regarding Abdelkader Dellas, Confédération générale du travail, Fédération nationale des syndicats des services de santé et des services sociaux CFDT, Fédération nationale de l'action sociale Force ouvrière c. Premier ministre, Ministre des Affairessociales, du Travail et de la Solidarité, ECLI:EU:C:2005:728 (www.curia.eu); CJCE, $5^{\text {th }}$ chamber, Order of 11.01.2007, in case C 437/05, Jan Vorel v. Nemocnice Český Krumlov, ECLI:EU:C:2007:23 (www.curia.eu).
} 
the employer's disposal in particular conditions ${ }^{3}$, which gave rise to new problems regarding the delimitation of working time by the rest time.

Particular problems in this regard raise the situation of employees who, by the nature of their attributions or the way in which the employer's activity is organized, have stable accommodation in the same place where the workplace is located or in its immediate proximity, being in the same time present in their own residence and at work place, readyto intervene at any time if they would be asked to.

This issue does not concern home workers or teleworkers, whose situations have special regulations that give rise to specific problems ${ }^{4}$; also, in the assumed hypothesis, do not fall employees who, due to the specific nature of their activity, are entitled to periods of rest at the workplace, in the case that it is impossible to return home after the end of normal working hours ${ }^{5}$.

The assumed hypothesis, which raises legal issues regarding the delimitation of working time from rest time, refers to the situation of those employees who are forced, due to circumstances resulting from the employment relationship, to live and spend time in resting places situated at the workplace which they cannot choose completely freely, those being practically expressly imposed by their employer or implicitly by their job duties.

In the context of the development of the concept of working time and the constant jurisprudence of the CJEU in the sense that, in general, periods during which the worker is present in his own residence, even if at the employer's disposal, must be regarded as rest time ${ }^{6}$, the question was whether a period during which the employee is at the disposal of the employer and may be required to resume work at any time may be included in working time, even if the employee is in his or her place of residence, when that residence is located at the work place.

${ }^{3}$ CJEU $-5^{\text {th }}$ chamber, judgement of 21.02.2018 in case C-518/15, Ville de Nivelles c. RudyMatzak, published at www.curia.eu; see also R. Anghel, Perioada de gardă la domiciliu poate constitui timp de lucru. Nuanţări recente în jurisprudenţa CJUE, „Curierul Judiciar” no. 3/2018, p. 150 et seq.

${ }^{4}$ see R. Anghel, Noua reglementare privind telemunca. Probleme specifice privind delimitarea timpului de lucru de timpul de odihnă în cazul telesalariaţilor, „Curierul Judiciar” no. 4/2018, pp. 209-218.

5 for example, according to Directive 2002/15/CE, for mobile workers that drive the vehicle in a team, it is considered rest time the period spent sitting next to the driver or in couchette while vehicle is in motion; according to the Directive 2014/112/UE, in the case of inland waterway transoport, rest time includes also the rest periods on a moving craft or on a stationary craft; it is also the situation of military personel that accomplishes military service in a military base, including when participate at exercises and manoeuvres where it cannot be considered working time the whole duration of a day, including the time intended and used for rest in the area where the activity take place - see R. Anghel, Delimitarea timpului de lucru de timpul de odihnă şi remunerarea muncii suplimentare şi de noapte în cazul personalului militar voluntar, "Curierul Judiciar" no. 2/2018, p. 70.

${ }^{6}$ CJEU - judgement of 03.10.2000, in case C-303/98, regarding Sindicato de Médicos de Asistencia Pública (Simap), Judgement of 09.09.2003, in case C-151/02, regarding Landeshauptstadt Kiel v. Norbert Jaeger, ECLI:EU:C:2003:437, par. 44-71 of the reasoning and the operative part; see also Răzvan Anghel, op. cit. („Timpul de lucru si timpul de odihna ...”), pp.75-76. 
In this context, investigating the jurisprudence of the courts of other EU Member States is very useful in identifying solutions for problems that Romanian courts may also face someday, since all these courts are considering the same regulation, namely Directive 2003/88 concerning certain aspects of the organisation of working time.

\section{Applicable criteria for delimiting working time from rest time}

In Grigore case, the Court held that, in interpreting Article 2 (1) of Directive 2003/88, the classification of a period as "working time" "does not depend on the provision of a service home within the canton under the management of the forester in so far as the making available of a dwelling does not imply that he is required to be present physically at the place determined by the employer and to remain at his disposal in order to be able to carry out the appropriate activities as soon as possible"7.

From this judgment reasoning, it follows as a principle thatthe existence of a living space in the space which constitutes also the work placeper se is not of such significance as to lead to the conclusion that the time spent by the employee in the dwelling is neither working time nor rest time; the Court stated that, for the purpose of delimiting working time from rest time in this case, the criteria already laid down in its case-law must be applied: if the worker is at the disposal of the employer in order to be able to carry out the necessary actions immediately; if he is unable to choose his place of residence during periods of inactivity or, after his working time of 40 hours a week the employee is able to organize his/her time, to leave the forestry canton under his management and to devote himself to his own interests ${ }^{8}$, the national court being the one who has to check these issues.

In other words, the fact that a space within the workplace is used as a residence does not necessarily mean that the entire period spent in this space is resting time and the fact that this space of residence is located inside the space that constitutes the work place does not necessarily mean that the entire period spent in that place is working time, being necessary to verify the fulfillment of other defining features of working time.

The fact that Article 2 of Directive 2003/88 is not one of the derogating provisions of the directive ${ }^{9}$, combined with the difficulty of delimiting working time in the case of certain occupations involving the provision of work in a space which is also used as a place of residence, at least temporarily ${ }^{10}$, as well as the fact

${ }^{7}$ CJEU, $6^{\text {th }}$ Chamber, Order of 04.03.2011, in case C-258/10, regarding Nicuşor Grigore v. Regiei Naţionale a Pădurilor Romsilva - Direcţia Silvică Bucureşti, ECLI:EU:C:2011:122.

8 par.66-68 of the judgement.

9 CJEU - judgement in case Grigore, cited, par.45 and CJEU, $3{ }^{\text {rd }}$ Chamber, judgement of 10.09.2015, in case C- 266/14, regarding Federación de Servicios Privados del sindicato Comisiones obreras(CC.OO.) c. Tyco Integrated Security SL, Tyco Integrated Fire \& Security Corporation Servicios SA, ECLI:EU:C:2015:578, par.28.

${ }^{10}$ see for such difficulties Dimitriu, Raluca, Munca în spatiul privat, „Revista Română de Dreptul Muncii" no. 9/2013, pp. 23-32. 
that staying at the employer's disposal in order to carry out the work determines the loss of some of the rest time features, caused the CJEU to be asked by the national courts a series of questions concerning other aspects regarding those professions such as weekly rest but also generated an extensive interpretation in the national case-law of the notion of location imposed by the employer where the employee must be present, even if there is also the place of residence, as will be shown below, precisely because that destination of a space does not have a decisive influence in defining and delimiting working time from rest time as established by CJUE in Grigore case.

It has been said that in the case of work done in an area which is also the residence of the employee, the conclusions of the CJEU in the SIMAP case could be used in the sense that only the time used for actual work should be considered as working time, the employee being in a situation similar to that of employees that are at the employer's disposal at home ${ }^{11}$. Although the idea to assimilate the situation of an employee working in some place that is also his residence with that of the employee at the employer's disposal and working only if required is not deserving a de plano rejection, it does not solve the problem of the difficulty of delimiting working time from rest time and that of the effective control able to ensure the employee's right to limit working time ${ }^{12}$ and benefit of minimum rest periods and also to protect the employer from the possible abuse of the employee that could declare unreal hours of work.

On the other hand, a distinction must be made between the situation where the worker turns his or her place of residence into a work placeand that situation where the employee establishes his/her residence in a place imposed by an employer who is in situ at the workplace. It is possible that this problem cannot be solved, which is why there are created forms of establishing a presumed working time, comparatively for example to a worker working at the employer's premises ${ }^{13}$, or there are identified forms of establishing result-oriented work relations in the sense that the employee's obligations are considered fulfilled when there are achieved certain goals without relevance to the length of the working time involved and, implicitly, to its delimitation from rest time ${ }^{14}$.

A specific problem in this regard is increasingly encountered in the case of staff engaged in childcare services which requires continuity of work in special

${ }^{11}$ Enescu, Andreea-Laura, Timpul de muncă şi de odihnă în dreptul naţional şi dreptul Uniunii Europene, Ed. CH Beck, Bucharest 2012, p.29.

12 in one study was shown that flexible organisation of work can lead to situations where there is kept no records of working hours and the unpaid supplementary work can often be done - see Alves, Paulo, Stephen Bouquin, and Luís Poças, Working time in European SMEs., "Transfer: European Review of Labour and Research" 13.1 (2007), p.90, available at http://journals.sagepub.com/ doi/abs/10.1177/102425890701300108, consulted on 07.11.2018.

${ }^{13}$ Dimitriu, Raluca, Munca în spaţiul privat, "Revista Română de Dreptul Muncii" no. 9/2013, pp. 25-26.

${ }^{14}$ Rubery, Jill, et al. Working time, industrial relations and the employment relationship, „Time \& Society" 14.1 (2005), p.92. 
care centres where the staff is resident, a different situation from that in which the child is taken up and cared for in the social worker's home ${ }^{15}$.

In such cases, even accepting the difficulty of delimiting working time from rest time, and even on the assumption that the working time of the employee does not exceed 8 hours a day, it is the question of the impossibility of taking weekly rest, since the activity continues seven days a week, but also the daily rest $^{16}$, the only accessible approach at this time being to verify the possibility of derogation established by art. 17 of Directive 2003/88; by applying Articles 3, 4 and 5 of that Directive, it may be may imposed to EU Member States to adopt clearer rules to ensure that the work is carried out in such a way that the delimitation of working time by rest time can be more easily achieved and in a clear manner, since, according to settled case-law of CJUE, the provisions transposing a directive must allow individuals to relate to a clear, precise and unequivocal legal framework ${ }^{17}$.

Thus, in the Isère case $^{18}$, it was established that employees who continuously supervise children in holiday and recreation centres where they reside during the contractual period may be exempted from the provisions on daily rest on the basis of Article 17 (3) (b) and/or (c) of Directive 2003/88, but only if the requirements laid down in Article 17 (2) of that directive are satisfied meaning to ensure them compensating rest periods or, in exceptional cases, appropriate protection $^{19}$. It is true that case it was not explicitly address the issue of the delimitation of working time from rest time but implicitly, by addressing the question of the non-observance of the right to daily rest, it was raised the question including in the working time of a period longer than 8 hours of activity by taking in consideration the employee's stay in the holiday centre and at the employer's disposal as much as the continuity of the activity in this type of care centres.

A similar problem was encountered in the case of employees of an association which had as their objective the protection of children, and provided for the children it took care of a home as similar as possible to a family home, in seven

15 for particular isues determined by this situation see Al. Athanasiu, L.E. Dima, T. Tunsoiu, A.-M. Vlăsceanu, Dezlegarea unor chestiuni de drept privind dreptul la concediu al asistenţilor maternali profesionişti (http://www.juridice.ro/469169/dezlegarea-unor-chestiuni-de-drept-privind-dreptul-laconcediu-al-asistentilor-maternali-profesionisti.html, consultat 07.11.2018); R. Anghel, Timpul de lucru al asistenţilor maternali profesioniş̧ti. Problema remunerării pentru munca prestată în zilele de repaus săptămânal - practică judiciară neunitarăa, „Curierul Judiciar” no. 2/2017, p. 73 and R. Anghel, Timpul de lucru al asistenţilor maternali profesionişti. Problema remunerării pentru munca prestată în concediul anual de odihnă - practică judiciară neunitară, „Curierul Judiciar” no. 3/2017, p. 133-137.

16 as CJEU noted in case Grigore, par.57 of the judgement.

${ }^{17}$ CJEU - judgement in case European Comision v. Irleland, C-87/14, EU:C:2015:449, pct.41 and che case law cited there, CJEU, $9^{\text {th }}$ Chamber, judgement of 23.12. 2015, in case European Comision v. Grece, C-180/14, EU:C:2015:840, par.40.

18 CJEU, $2^{\text {nd }}$ Chamber, judgement of 14.10 .2010 , in case C-428/09, regarding Union syndicale Solidaires Isère v. Premier ministre, Ministère du Travail, des Relations sociales, de la Famille, de la Solidarité et de la Ville, Ministère de la Santé et des Sports, ECLI:EU:C:2010:612.

${ }^{19}$ operative part of the judgement. 
villages of children each comprising several children's homes which is home to the children being cared for and accommodates between three and six children, as well as one or more titular "parents" (or their substitutes, if the titular "parents" are missing)

CJUE decided that Article 17(1) of Directive 2003/88/EC must be interpreted as meaning that it cannot apply to paid work, such as that at issue, "which consists in caring for children in a family-like environment, relieving the person principally responsible for that task, where it is not established that the working time as a whole is not measured or predetermined or it may be determined by the worker himself, which is for the national court to ascertain"20.

In fact, in this case, the problem also arises from the evidence that the care and supervision of children in such centers meets the characteristic features of working time, but the way in which the work is done makes it very difficult within the existing legislative framework to delimit working time from rest time. However, even if the duration of the working time is not measured and/or predetermined or can be determined by the workers themselves, Article 17 of Directive 2003/88 does not allow derogation from the provisions of Article 2 thereof.

The period in which the employee is at home, but this residence is imposed by the employer, and in which the employee must be at the employer's disposal to intervene at any time, may be assimilated to the time spent on call at a place imposed by the employer.

However, the three features of working time must be met cumulatively ${ }^{21}$, and it is not sufficient for the employee to be at the employer's disposal and to exercise his/her duties or functions but also to be at the workplace or in a place imposed by the employer so that periods in which the employee is at home or in another place freely chosen by him or her does not constitute working time even if the employee must be available to the employer for the purpose of performing the work unless the conditions imposed by the employer are such as to objectively make the employee unable to dedicate himself to his personal activities, limiting his freedom of action ${ }^{22}$.

When the employee remain at his/her place of residence, which is at work place, he/she has to prove that during that period of time has worked or has been available to the employer in the sense of being continuously prepared as at any

${ }^{20}$ CJEU - $4^{\text {th }}$ Chamber, judgement of 26.07.2017 in case C-175/16, regarding Hannele Hälvä, Sari Naukkarinen, Pirjo Paajanen, Satu Piik v. SOS-Lapsikyläry, ECLI:EU:C:2017:617, operative part.

${ }^{21}$ European Comision, Communication [...] on the organisation of working time in the sectors and activities excludedfrom Directive 93/104/EC, COM (1998)662 final - Explanatory memorandum, published at ec.europa.eu/social/Blob Servlet?docId=2933\&lang Id=en, consulted on 07.11.2018, p. 12 pct.6; for the same opinion see also Del Giudice, Federico, Izzo, Fausto, Solombrino, Mariarosaria, Manuale di diritto del lavoro, ed.XXXIV, Ed. Simone, Napoli, 2016, p.244.

${ }^{22}$ CJEU $-5^{\text {th }}$ Chamber, judgement of 21.02 .2018 in case C-518/15, regarding Ville de Nivelles c.Rudy Matzak. 
time, if necessary and required, to start work, and not just the fact that there is a theoretical possibility to be asked to intervene, given that he is anyway at work ${ }^{23}$.

However, it should be noted that during the planned periods of interruption in activity, although the worker may still be at the workplace, the employee is not at the employer's disposal and in the exercise of her/his duties or functions, even if she/he may exceptionally be required to resume work, since this interruption of work is not incompatible with performing of eventual and exceptional interventions required by the employer during that time, if necessary, especially for security reasons (in which case the intervention itself will be considered for determining the duration of actual work ${ }^{24}$.

However, the situation must be examined in concrete terms by the courts on a case-by-case basis, the CJEU establishing in the Grigore case also a few elements that need to be verified respectively: concrete factual situation and not just legal or contractual theoretical regulation; whether the employee has material and disciplinary liability for what is happening at the workplace during that period, especially if he or she isthe only person liable; if there is a system to ensure shift work by other employees ${ }^{25}$.

So, what is to be checked out is whether, although the residence is at the workplace, there are periods that can be classified as rest periods in which a worker can handle personal interests, even leaving that home and the work place without to be asked to stay in that place to be ready to work at any moment.

\section{Applying the criteria in the national jurisprudence of the EU Member States}

In the judicial practice of the European Union courts there are examples where, when the worker is residingat the workplace, it is considered that the entire period in which the employee is in that place must be considered as working time.

Thus, in the Belgian case - law it was held thatit must be considered as working time, the entire period during which an employee of a non-stop service company is at home, without actually doing anything but sporadically, but being at the disposal of the employer and its clients, being obliged to respond at any time to the orders which might have arisen in the particular circumstances of the case where the employee residence had been imposed by the employer by the employment contract in a service dwelling made available by him, located on the upper floor of the building in which the company had commercial space, in one of the periods, and, in another period, in a building with a direct access to the

${ }^{23}$ Anghel, R, Delimitarea timpului de lucru de timpul de odihnă şi remunerarea muncii suplimentare şi de noapte în cazul personalului militar voluntar, „Curierul Judiciar” no. 2/2018, p. 75.

${ }^{24}$ Cour de cassation, Chambre social, audience publique du 28.05.2014, $\mathrm{n}^{\circ}$ de pourvoi 13-10544, audience publique du 28.05.2014, $\mathrm{n}^{\circ}$ de pourvoi 13-13996 (www.legifrance.fr, consulted on 07.11.2018).

${ }^{25}$ CJEU, $6^{\text {th }}$ Chamber, Order of 04.03.2011, in case C 258/10, regarding Nicuşor Grigore, cited, par. $52,55,56$. 
commercial space; the applicant had a normal work schedule, but provided one week per month with a permanent service in which he carried out all the specific activities related to the provision of services on a non-stop basis; he subsequently accepted this permanent service for two weeks each month ${ }^{26}$.

In such a situation, practically there is no difference between a period of on-call duty at the work place and a period of on-call duty at home, the employee being in a residence imposed by the employer, which also corresponds to the criteria to define the working time imposed by the CJEU, that includes not only the employee's presence at the workplace, but also the presence at any place imposed by the employer ${ }^{27}$.

In several cases, the English case-law has dealt with the question of how to delimit working time from rest time in the case of workers employed in care facilities who were also resident in that facilitiypremises and were permanently at the disposal of the beneficiaries but also in other similar situations, making a distinction between employees who are remunerated just to be present at their place of work that isalso their place of residence, especially during the night, and employees who carry out on-call duty in such a space.In the context in which, under UK law, working time is regulated separately and differently for the purpose of remuneration and respectively for the purposes of protection of health and safety at work ${ }^{28}$, that difference was necessary to determine when it rise the question of working time remuneration and when is about the issue of compliance with the rules on health and safety at work. Thus, a first category of employees is the one whose work consists in the mere presence at work during the night, just in case of any event, during which they can even sleep, being asked to act only in the situation of an emergency, due to the fact that the employer has to comply with certain safety requirements that imply the permanent presence of an employee on the premises of the enterprise ${ }^{29}$; in this case, that period of time constitutes working

${ }^{26}$ Cour du Travail de Mons, $2^{\text {ème }}$ Chambre, arret du 18 janvier 2010, R.G. 2007/AM/20768, pp. 37 40; available at http://jure.juridat.just.fgov.belpdfapp/download_blob?idpdf $=F-20100118-8$, consulted on 07.11.2018; the appeal against this sentence was not against the problems presented here and was rejected by the Cassation Court of Belge by decision of 30.04.2012, see Răzvan Anghel, op. cit. („Timpul de lucru si timpul de odihna...”), p. 104-105.

${ }^{27}$ CJEU- judgement of 09.09. 2003, in case C-151/02, regarding Landeshauptstadt Kiel c. Norbert Jaeger, ECLI:EU:C:2003:437, par. 44-71 of the reasoning and the operative part; a contrario CJEU, $4^{\text {th }}$ Chamber, judgement of 09.07.2015, in case C- 87/14, European Comission v. Irleland, regarding the failure of a member state to fulfil obligations, brought under art. 258 TFUE ECLI:EU:C:2015:449.

28 The National Minimum Wage Regulations 2015 and The Working Time Regulations (1998), available at http://www.legislation. gov.uk/, consulted on 07.11.2018.

${ }^{29}$ for example it was decided that it must be considered working time the period when a worker is asked to sleep in the hotel here he is employed in the situation where he was fulfilling an obligation imposed by the employee that, on his part, was required to have in the building during the whole night at least two employees according to the regulations on health and safety and to the regulation on fire protection (United Kingdom Employment Appeal Tribunal Edinburgh, judgement of 30.05.2006, in case Anderson v. Jarvis Hotels Plc [2006] UKEAT 0062_05_3005 (30 May 2006); it was also decided in the same way in the case of an employee that was required simply to be present during night in a care facility for people in need, in order to be available in the 
time because it is actually used to perform the employment duties and is remunerated accordingly ${ }^{30}$ so that there are no problems in terms of working time, being only apparently an inactive period.Starting from those decided by the CJEU in the SIMAP and Jaeger cases, one appellate court held ${ }^{31}$ that the entire period in which an employee must remain in a workplace dwelling at the workplace and respond to the requests of the residents o a care center constitutes working time even if the worker can sleep at night or rest in his room because the extent to which the employee can be asked to work effectively is not decisive for determining working time (even if he is recognized that the chances for the applicant to be required to work effectively are lower than for doctors on call) and it is also irrelevant if the accommodation is intended or can be the residence of the employee.In that case, it was noted that the applicant had never been released from her duties since she was required to respond to the residents' direct requests, so that she remained in the place determined by the employer for the purpose of carrying out her duties in case of need or when requested to intervene. Consequently, it was concluded that the whole period whenthe employee was on duty must be considered working time.In other cases where the facts were considered to be the same, this precedent was used to establish that the entire period of time during which the employee was in the service residence at premises of the care center constitutes working time without considering it that the employee was actually working but was just on call ${ }^{32}$.. Instead, it was decided in the case of a temporary

case that an emergency situation should occur - Employment Appeal Tribunal London, judgement in case Burrow Down Support Services Ltd v Rossiter [2008] UKEAT 0592_07_2506 (25 June 2008), available at http://www.bailii.org/uk/cases/UKEAT/2008/0592_07_2506.html, consulted on 21.10.2018; Employment Appeal Tribunal London, hotărârea în cauza Esparon (t/a Middle West Residential Care Home) v Slavikovska , [2014] UKEAT 0217_12_0805 (8 May 2014), available at http://www.bailii.org/uk/cases/UKEAT/2014/0217_12_805.html, consulted on 21.10.2018; see Răzvan Anghel, Delimitarea timpului de lucru de timpul de odihnă în jurisprudenţa britanică, „Revista de Drept Social” no. 3/2017, p.15-16.

${ }^{30}$ Employment Appeal Tribunal London, judgement in case South Manchester Abbeyfield Society Ltd v Hopkins \& Anor [2010] UKEAT 0079_10_3011 (30 November 2010), available at http://www.bailii.org/uk/cases/UKEAT/2010/0079_10_3011.html, consulted on 21.10.2018.

${ }^{31}$ United Kingdom Employment Appeal Tribunal London, judgement of 31.01.2006, in case MacCartney v. Oversley House Management [2006] UKEAT 0500_05_3101 (31 January 2006), available at http://www.bailii.org/uk/cases/UKEAT/2006/0500_05_3101.html; before the judgement of CJEU in case, was decided contrary to that - United Kingdom Employment Appeal Tribunal London, judgement of 03.06.2003 in case South Holland District Council v Stamp\&Ors [2003] UKEAT 1097_02_0306 (3 June 2003), available at http://www.bailii.org/uk/cases/UKEAT/2003/1097_02_0306.html; see Răzvan Anghel, Delimitarea timpului de lucru de timpul de odihnă în jurisprudenţa britanică, , Revista de Drept Social" no. 3/2017, p.17-18.

${ }^{32}$ United Kingdom Employment Appeal Tribunal London, judgement of 03.10.2008 in case Hughes v. Jones \& Anor (t/a Graylyns Residential Home) [2008] UKEAT 0159_08_0310 (3 October 2008), available at http://www.bailii.org/uk/cases/UKEAT/2008/0159_08_0310.html; also in the case of some employees called "Resident Housing Support Worker" - Employment Appeal Tribunal Edinburgh, judgement in case City Of Edinburgh Council v Lauder \& Ors (Working Time Regulations) [2012] UKEAT 0048_11_2003 (20 March 2012, available at http://www.bailii.org/uk/cases/UKEAT/2012/0048_11_2003.html, consulted on 21.10.2018; Employment Appeal Tribunal London, judgement in case Smith v Oxfordshire Learning Disability 
restaurant manager (between the resignation of the former manager and the appointment of the new manager) who was required to sleep in the local area but without having any responsibility or attribution at night, being allowed even to leav the place for certain periods, that the time in question does not constitute working time within the meaning of the national minimum wage regulation, the purpose of the presence at the workplace being only a preventive and minimal security of property, as the risk of intrusion and theft would bu reduced by the fact that the space was inhabited whether someone is there at anytime or not; at the same time, if a danger situation arose, the employee would only have to act like any other citizen by calling on emergency services ${ }^{33}$; in that case, however, the court was not called upon to consider whether that period constituted working time within the meaning of the regulation on the organization of working time for the purposes of protection of health and safety at work.

In the British jurisprudence has been proposed as a criterion for determining the category in which each situation falls in, the reason why the employee is required to remain in a place of residence at the workplace. Thus, if the request is due to a legal obligation on the part of the employer to ensure the presence of an employee in the workplace just in case of any event, then he/she is part of the category of employees who are paid for the mere presence at the workplace, whether or not they work, which is their specific activity for which they are remunerated so that the period in question enters the working time for this reason ${ }^{34}$.

At the same time, it is interesting that in the case of Grigore, in which the CJEU's preliminary request was filed, the national court dismissed the action, holding that the collective labour agreement applicable in the forestry activity provides that the work schedule is not standardized, but it will fall within the normal duration of of the working time provided for by the legislation in force, so that the applicant is carrying out unusual working hours, being "[exempted] from the provision of overtime and [exempted] from work at night" ${ }^{35}$; it is nevertheless questionable to take in consideration an exemption under the collective labor

\footnotetext{
NHS Trust [2009] UKEAT 0176_09_2406 (24 June 2009), available at http://www.bailii.org/uk/cases/UKEAT/2009/0176__09_2406.html, consulted on 21.10.2018; Employment Appeal Tribunal London, judgement in case Shannon v Rampersad \& Anor (t/a Clifton House Residential Home) [2015] UKEAT 0050_15_2409 (24 September 2015), available at http://www.bailii.org/uk/cases/UKEAT/2015/0 050_15_2409.html, consultată la 21.10.2018; in this latter case it was taken in consideration that during the night there was another caretaker that was in service while the claimant was only required to give support to the other employee in case of need.

${ }^{33}$ Employment Appeal Tribunal London, hotărârea în cauza Wray v JW Lees \& Co (Brewers) Ltd. [2011] UKEAT 0102_11_1407 (14 July 2011), available at http://www.bailii.org/uk/cases/ UKEAT/2011/0102_11_1407.html, consulted on 21.10.2018.

${ }^{34}$ Employment Appeal Tribunal London, judgement in case Esparon (t/a Middle West Residential Care Home) v Slavikovska, [2014] UKEAT 0217_12_0805 (8 May 2014), cited, par.53.

${ }_{35}$ Ploieşti Court of Appeal, $2^{\text {nd }}$ Civil and administrative and fiscal cases Section, dec.no.1070/28.02.2012, published in Anghel, Răzvan, Timpul de lucru - Ghid de jurisprudenţă naţională, Ed. CH Beck, Bucharest, 2018, p. 17-21.
} 
agreement based on Article 17 (3) (b) of Directive 2003/88, since the facts of the case would lead to a derogation from the very Article 6 of the Directive, from which it is not permitted to derogate on that basis and that, moreover, was not provided for in the collective agreement envisaged.

The court casesregarding the staff in residential care homes for people in need are one that will continue to cause problems in the wider context of the litigations involving employees with the place of residence located at the workplace.

The situation resembles to a large extent to that of the Dellas, Grigore or Iserère cases, but the CJEU did not yet offer a clear resolution of the question of how to delimit working time from rest time in such cases.

\section{Conclusions}

The recent nuances made by the CJEU in the Matzak case, according to which working time can even be the time spent at home, if restrictive conditions are imposed so that the period cannot be considered as rest time, even more a period spent in a residence located at the workplace must be regarded as working time if the employee is required to live at the workplace and to be available at any time to resume his/her activity as a general rule, so that implicitly the employee must remain permanently in that place, and there is not put in place a shift work system. Even if the employee can even rest during this time, if that time period is not explicitly intended for rest and if in fact the employee is not totally relieved of any duties, except for emergency situations, that period cannot be considered as rest time and since the two concepts are mutually exclusive ${ }^{36}$, it must be considered working time. If, however, although the residence is at the workplace, the employee benefits from periods in which he is completely relieved of the responsibilities of the activity, those must be regarded as rest time.

When an employee's duties consist of mere attendance at the workplace, in order to comply with certain legal obligations regarding the safety of certain activities, persons or goods, that is not an inactive period but a period of effective work so it is part of working time; in such a situation there can be found an employee who has other tasks in the normal work program. Even more so, if the employee's duties are the same during both normal work program and after the normal working hours, i.e. to be present and vigilant for the purpose of protecting goods and people, there is no difference between the two periods. However, the situation is no different if this obligation of attendance and vigilance is imposed by the employer for the proper conduct of the activity. It is different, however, where the employee is only required to be at the employer's disposal and ready to resume work at any time when asked, without being subject to vigilance and supervision but only beng requested to respond to an alarm, possibly while other employees are charged with this responsibility, in which case it constitutes a period of on call duty

${ }^{36}$ among others, CJEU judgement în case Matzak, cited, par.55. 
that falls within the notion of working time. If, however, this obligation to reside at the workplace is not accompanied by any responsibility, being merely facilitating the activity or even being a favor for the employee, that is free to leave the location outside the normal working hours, the period should be considered rest time even if, in case of an emergency, it would be espected from his part to act as any normal citizen by trying to do the best to limit the consequences of the hazard and to call the emergency services.

\section{Bibliography}

1. Alves, Paulo, Stephen Bouquin, and Luís Poças, Working time in European SMEs, „Transfer: European Review of Labour and Research" 13.1 (2007).

2. $\quad$ Anghel, Răzvan, Timpul de lucru și timpul de odihnă - Jurisprudenţa Curţii de Justitie a Uniunii Europene, Ed. Universul Juridic, Bucharest, 2017.

3. Anghel, Răzvan, Perioada de gardă la domiciliu poate constitui timp de lucru. Nuanţări recente în jurisprudenţa CJUE, „Curierul Judiciar” no. 3/2018.

4. Anghel, Răzvan, Noua reglementare privind telemunca. Probleme specifice privind delimitarea timpului de lucru de timpul de odihnă în cazul telesalariaţilor, „Curierul Judiciar" no. 4/2018.

5. Anghel, Răzvan, Delimitarea timpului de lucru de timpul de odihnă şi remunerarea muncii suplimentare şi de noapte în cazul personalului militar voluntar, „Curierul Judiciar" no. 2/2018.

6. Anghel, Răzvan, Delimitarea timpului de lucru de timpul de odihnă în jurisprudenţa britanică, „Revista de Drept Social” no. 3/2017.

7. Anghel, Răzvan, Timpul de lucru - Ghid de jurisprudenţă națională, Ed. CH Beck, Bucharest, 2018.

8. Anghel, Răzvan, Timpul de lucru al asistenţilor maternali profesionişti. Problema remunerării pentru munca prestată în zilele de repaus săptămânal - practică judiciară neunitară, „Curierul Judiciar” no. 2/2017.

9. Anghel, Răzvan, Timpul de lucru al asistentilor maternali profesionişti. Problema remunerării pentru munca prestată în concediul anual de odihnă - practică judiciară neunitară, „Curierul Judiciar” no. 3/2017.

10. Athanasiu, Alexandru, Dima, Luminiţa Elena, Tunsoiu, Traian, Vlăsceanu, AnaMaria, Dezlegarea unor chestiuni de drept privind dreptul la concediu al asistenţilor maternali profesionişti (www.juridice.ro/46 9169/ dezlegarea-unor-chestiuni-dedrept-privind-dreptul-la-concediu-al-asistentilor-maternali-profesionisti.html, consulted on 1.10.2018).

11. Del Giudice, Federico, Izzo, Fausto, Solombrino, Mariarosaria, Manuale di diritto del lavoro, ed. XXXIV, Ed. Simone, Napoli, 2016.

12. Dimitriu, Raluca, Munca în spaţiul privat, „Revista Română de Dreptul Muncii” no. $9 / 2013$.

13. $\quad$ Enescu, Andreea-Laura, Timpul de muncă şi de odihnă în dreptul naţional şi dreptul Uniunii Europene, Ed. CH Beck, Bucharest, 2012.

14. Rubery, Jill, et al., Working time, industrial relations and the employment relationship, „Time \& Society” 14.1, 2005. 